\title{
Środowiskowa krzywa Kuznetsa jako rama wzajemności świadczeń w polityce prawa
}

\begin{abstract}
Streszczenie
Środowiskowa krzywa Kuznetsa jest formułą opisu asymetrii uwarunkowań rozwoju gospodarczego i wynikających stąd sprzeczności interesów pomiędzy państwami. Owe asymetrie i sprzeczności znajdują odzwierciedlenie w realizowanej przez nie wewnętrznie i poszukiwanej w przestrzeni międzynarodowej policy mix w dziedzinie ochrony środowiska. Na mapie interesów i zależności naturalnie pojawiających się w kontekście ochrony środowiska muszą być uwzględnione korzyści i koszty zewnętrzne, które stwarza polityka ochrony środowiska poszczególnych państw. Z EKC wynika, że owe korzyści i koszty nie mogą być rozłożone równomiernie, co powoduje, że istotne jest zapewnienie takich rozwiązań międzyjurysdykcyjnych, które zapewniają identyfikację świadczeń opartych na wzajemności zgeneralizowanej i realizację ich w jakiejś formule wymagającej międzynarodowego porozumienia o wymianie świadczeń w postaci kooperatywnych elementów polityki ochrony środowiska oraz transferów finansowych. Wzajemność, o której w tym wypadku mowa, ma charakter zgeneralizowany. Jej funkcją jest zapewnienie takich równowag Nasha, które długookresowo zapewniają najwyższy poziom efektywności. Jakkolwiek wyzwala to pewien stopień niekooperatywności w krótkim i średnim okresie, to jednak nie jest ona zupełna, gdyż fundamentalne, długookresowe cele polityki środowiska większości państw są podobne.
\end{abstract}

Słowa kluczowe: środowiskowa krzywa Kuznetsa, ochrona środowiska, ochrona krajobrazu, wzajemność, polityka prawa

\section{Environmental Kuznets Curve as a Framework of Favours Reciprocity in the Policy of Law}

\begin{abstract}
The Environmental Kuznets Curve (EKC) is a descriptive formula used to reflect on asymmetries in economic development and consequential conflict of interests arising between various states of the world. These asymmetries and conflicts of interests have
\end{abstract}


their reflection in these states' environmental policy mix - implemented domestically and pursued in the international context. The emerging map of mutual interests and dependences results from the consideration of external costs and benefits pertaining to respective national environmental policies. The EKC makes it evident that these costs and benefits cannot be evenly spread over all the states. This urges these states to adopt such interjurisdictional arrangements which are based on the identification of a possible multilateral exchange of economic policy favours and international financial transfers. Such an exchange, whenever occurs, has a generalized reciprocity formula. The function of such an arrangement is to make it possible for Nash equilibria to emerge, as such are most likely to produce the highest possible level of effectiveness in the long run. Such a behavior may not be cooperative in the short and medium term, yet the bottom-line cooperativeness is achieved because most states have similar if not the same long-term environmental goals.

Keywords: Environmental Kuznets Curve, environmental protection, landscape protection, reciprocity, policy of law

Celem opracowania jest rozważenie asymetrycznych aspektów antropogenicznych zmian środowiska naturalnego w układzie międzynarodowym. Asymetria w tym zakresie pojawia się bowiem $\mathrm{w}$ wielu aspektach: $\mathrm{w}$ modelu inicjowania wspomnianych zmian, w przebiegu zjawisk do nich się odnoszących, a także - co za tym idzie - w polityce publicznej, której funkcją jest ograniczenie zakresu i głębokości negatywnych skutków środowiskowych wywołanych działalnością człowieka tak w samym państwie, które politykę publiczną realizuje, jak i poza nim - w postaci, która jest relewantna dla stanu występującego w nim środowiska naturalnego.

W wymiarze międzynarodowym zapobieganie negatywnemu wpływowi działalności człowieka na środowisko naturalne wymaga współpracy państw, która musi zmierzać również do wyeliminowania zjawiska ,jazdy na gapę” (free ride). Efektywna ochrona środowiska przez jedno państwo wymaga zatem nie tylko podejmowania przez nie samo określonych działań ochronnych, ale również negocjowania takich rozwiązań, które eliminują zjawisko „jazdy na gapę” w skali międzynarodowej poprzez znalezienie formuły jakiegoś kooperatywnego sposobu współdziałania. W warunkach występującej asymetrii korzyści i kosztów, które stąd mogą wynikać, wymaga to znalezienia kompromisowych rozwiązań umownych - takich, które zapewniają jakąś formułę wzajemności świadczeń umawiających się państw. Właśnie ta kwestia jest zasadniczym tematem tego opracowania. Jest tu rozważana w kontekście środowiskowej krzywej Kuznetsa, która stanowi koncepcję nadającą kwestii asymetrii kosztów i korzyści z ochrony środowiska odpowiedni stopień analitycznego rygoryzmu. 
Dla potrzeb opracowania przyjęto koncepcję polityki prawa Maura Zamboniego. Zgodnie z nią, tego rodzaju polityka może być definiowana jako zespół działań i standardów (w tym procedur) służących przetworzeniu politycznych wyborów (mających odpowiednie osadzenie aksjologiczne) w tetyczne narzędzia ich realizacji, tj. w prawo ustanawiane przez legitymowane do tego organy ${ }^{1}$.

\section{Środowiskowa krzywa Kuznetsa}

Środowiskowa krzywa Kuznetsa (Environmental Kuznets Curve, EKC) przedstawia graficznie statystyczną korelację poziomu aktywności gospodarczej (albo jakiejkolwiek innej miary dobrobytu materialnego) i wynikającego z tej aktywności obciążenia dla środowiska naturalnego. Poprzez obciążenie należy rozumieć obniżenie jego jakości stanowiące następstwo antropogenicznych (konkretnych) zanieczyszczeń, jak również jego rekonfigurację, polegającą w szczególności na zniekształceniu krajobrazu czy deplecji zasobów. W tym pierwszym przypadku poziomy zanieczyszczania określonymi substancjami szkodliwymi mogą być i są traktowane jako uogólniony wskaźnik poziomu gospodarczego korzystania ze środowiska (a tym samym rozmiarów określonego typu, uciążliwej dla środowiska, aktywności gospodarczej); w drugim przypadku (dotyczącym zniekształcenia krajobrazu) ów wskaźnik jest jakościowy i trudno mierzalny, ale za to pokazujący kulturowe aspekty korzystania ze środowiska; w trzecim zaś przypadku (odnoszącym się do deplecji środowiska, zwłaszcza jednak jej modelu oraz tempa), wskaźnik, o którym mowa, może być interpretowany jako taki, który wskazuje zależność gospodarki od pobranych ze środowiska zasobów.

Obciążenie ujawnione w EKC wynika stąd, że - na obecnym etapie rozwoju technologicznego - każda działalność gospodarcza powoduje środowiskowe koszty zewnętrzne $z$ tej racji, że jest ona oparta na eksploatacji zasobów pobieranych ze środowiska naturalnego ${ }^{2}$. To, co różnicuje państwa, to jednak wydajność tego działania: niektóre gospodarki wytwarzają bowiem produkty i usługi w sposób intensywny środowiskowo (tj. polegający na intensywnym obciążaniu środowiska naturalnego), podczas gdy inne modele gospodarcze, $w$ tym stosowane w nich technologie, mogą pozwalać na zmniejszenie tej intensywności. W odniesieniu do krajobrazu zasadniczą determinantą modelu zachowań gospodarczych jest natomiast popyt na dobra będące jego składnikami (np. nieruchomości położone na terenie o znacznych walorach

1 M. Zamboni, The Policy of Law: A Legal Theoretical Framework, Hart, Oxford 2007, s. 129-135.

2 S. Kuznets, Economic Growth and Income Inequality, "The American Economic Review" 1955, Vol. 45 , s. 1-28. 
estetycznych), wobec których popyt na krajobraz jest komplementarny. Sama EKC w odniesieniu do krajobrazu jest jednak - właśnie z tego powodu - bardzo trudna do wyznaczenia.

Środowiskowa krzywa Kuznetsa (EKC) przedstawia wspomnianą relację następująco:

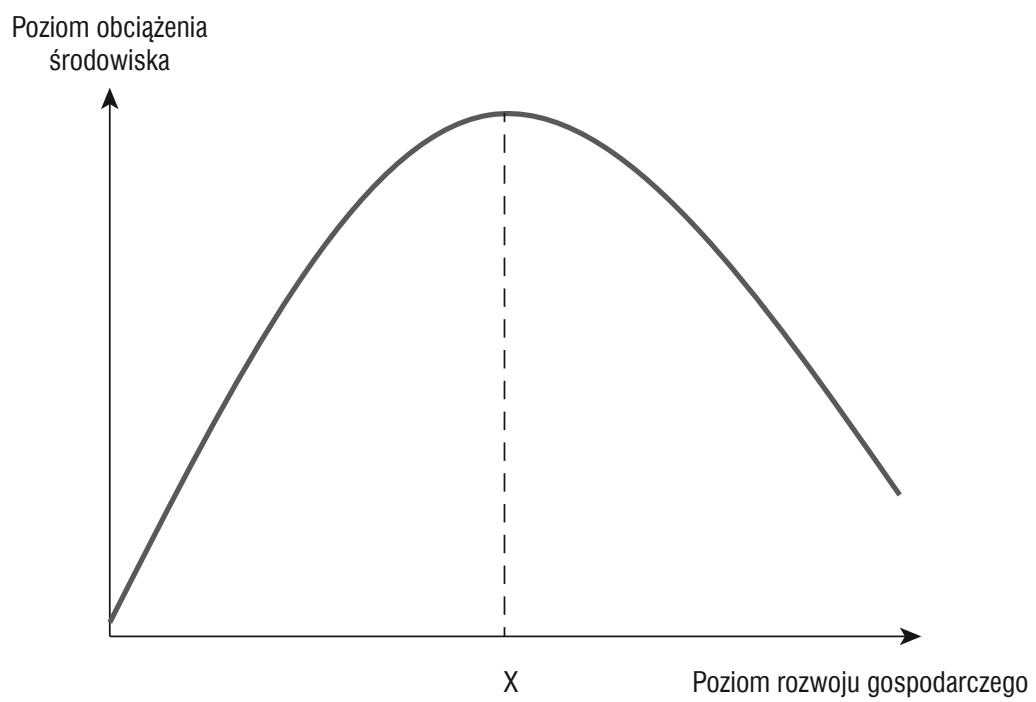

Rysunek 1. Środowiskowa krzywa Kuznetsa (EKC)

Źródło: S. Kuznets, Economic Growth and Income Inequality, “The American Economic Review” 1955, Vol. 45, s. $1-28$.

Relacja pomiędzy poziomem rozwoju gospodarczego a poziomem obciążenia środowiska przedstawiona przez EKC jest taka, że najniższemu poziomowi rozwoju gospodarczego przypisany jest najniższy poziom obciążenia środowiska naturalnego. Przy średnim poziomie rozwoju gospodarczego (aktywności gospodarczej) poziom obciążenia wzrasta i osiąga najwyższą wartość. Jednocześnie właśnie na tym poziomie występuje przełamanie EKC, co oznacza, że poziom obciążenia środowiska zaczyna spadać3. Przyczyną tego zjawiska jest zwiększający się, w wystarczająco wysoko rozwiniętych gospodarkach, udział dóbr i usług nieintensywnych środowiskowo w katalogu wszystkich dóbr i usług w takich gospodarkach wytwarzanych. To z kolei jest efektem zmian w proporcjach międzygałęziowych, a także postępu technicznego,

3 Zob. np. potwierdzenie tych konkluzji w badaniach empirycznych: G.M. Grossman, A.B. Krueger, Economic Growth and the Environment, "Quarterly Journal of Economics" 1995, Vol. 110, s. 353-377 oraz kontestację twierdzeń w: A.A. Bartlett, Reflections on Sustainability, Population Growth and the Environment, "Population and Environment" 1994, Vol. 16, s. 5-35. 
który umożliwia wydajniejsze wykorzystywanie zasobów w procesach wytwórczych. Spadek obciążenia środowiskowego gospodarek wysoko rozwiniętych można także przypisać procesom globalizacyjnym, które umożliwiają przeniesienie działalności najbardziej intensywnych środowiskowo poza dane państwo. Zjawisko to będzie występowało w szczególności wtedy, kiedy w państwie tym zostaną wprowadzone regulacje zmierzające do internalizacji kosztów zewnętrznych przez tych, którzy je powodują. Przeniesienie jest w takim wypadku swoistą „jazdą na gapę”, w której zamiast stwarzać w danej jurysdykcji presję środowiskową i narażać się na internalizację tego kosztu zewnętrznego, przedsiębiorstwa przeniosą przyczyny tej presji poza tę właśnie jurysdykcję.

Wielu badaczy uważa, że EKC jest zdeterminowana przez skalę, strukturę, a także bazę techniczną gospodarki, do której się ta krzywa odnosi. W ujęciu N. Islama, J. Vincenta i T. Panayotou czynnik skali obrazuje taką relację, że wraz ze zwiększonym tempem rozwoju gospodarczego rośnie presja działalności gospodarczej (zwłaszcza produkcji) na środowisko. Proces ten może być łagodzony (lub nie - zależnie od sytuacji na poziomie krajowym) przez drugi czynnik kształtujący EKC: zmiany w strukturze tej działalności gospodarczej (czyli zasadniczo w strukturze towarów i usług wytwarzanych w gospodarce). W EKC istotną rolę odgrywa także czynnik techniczny: państwa bogatsze mogą posługiwać się technologiami i rozwiązaniami organizacyjnymi, które gwarantują stosunkowo wysoką społeczną produktywność (co implikuje niskie koszty zewnętrzne, a zatem i słabszą presję na środowisko). Siła oddziaływania efektu skali ujęta w EKC jedynie zwiększa się w miarę podwyższenia poziomu rozwoju gospodarczego. Czynniki strukturalne korelują z procesem degradacji środowiska tak, że do pewnego poziomu tego rozwoju zwiększają jej tempo i skalę. Przy pewnym poziomie dobrobytu (związanym z tempem wzrostu) już ta korelacja jest jednak negatywna. W ujęciu Islama, Vincenta i Panayotou na EKC wpływa także efekt redukcji. Argument ten odwołuje się do prawa Engla i ujmuje poziom degradacji środowiska jako monotonicznie malejącą funkcję dochodu. W takim ujęciu krzywa redukcji wyznaczana jest jako zbiór punktów równowagi poziomów redukcji, tj. takich punktów, w których podaż i popyt - zależne od dochodów - są równe ${ }^{4}$.

W ujęciu wręcz podstawowym warto zwrócić uwagę, że EKC, traktowana jako narzędzie analityczne, sama w sobie nie determinuje kierunków i narzędzi polityki ochrony środowiska, a zatem i polityki publicznej. O tym wyborze decyduje przede wszystkim wielkość danej jurysdykcji oraz ogólna postać jej powiązania z resztą świata. Inaczej swoją pozycję na EKC będą bowiem traktować jurysdykcje małe

4 N. Islam, J. Vincent, T. Panayotou, Unveiling the Income-Environment Relationship: An Exploration into the Determinants of Environmental Quality, Development Discussion Paper 1999, No. 701, s. 5. 
i autarkiczne, a inaczej duże i otwarte. Zasadniczy problem asymetrii bardzo dużych i zróżnicowanych jurysdykcji polega na tym, że duże jurysdykcje integrujące wiele mniejszych jednostek jurysdykcyjnych mogą poniekąd plasować się w zbiorze rozmytym - po obu stronach krzywej Kuznetsa. W odniesieniu do jurysdykcji wystarczająco małych jest zupełnie inaczej - w zależności od poziomu rozwoju gospodarczego mogą być one plasowane na tylko jednym punkcie leżącym na EKC. Panayotou konceptualizuje sytuację w miarę trwałego zróżnicowania pozycji poszczególnych państw na krzywej EKC w następujący sposób (linie odcięte wskazują alternatywne ścieżki rozwoju przykładowych dwu jurysdykcji uplasowanych na przeciwstawnych ramionach elipsy EKC):

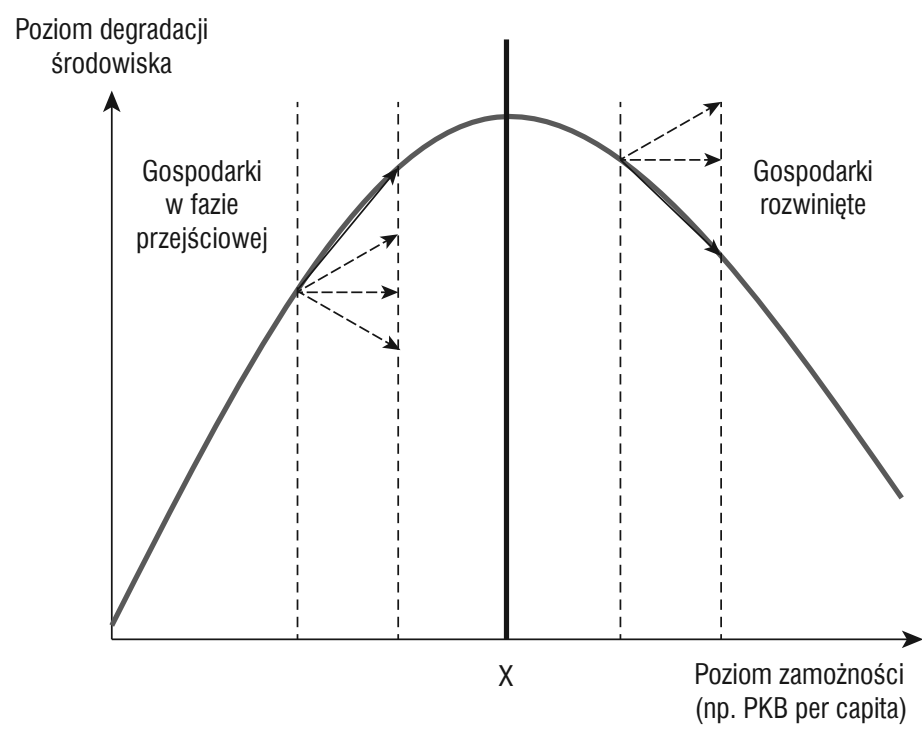

Rysunek 2. Gospodarki w fazie przejściowej oraz gospodarki rozwinięte na krzywej środowiskowej Kuznetsa

Źródło: T. Panayotou, Economic Growth and the Environment, Economic Survey of Europe 2003, Economic Commission for Europe, s. 58.

Ścieżki rozwoju przedstawione na przykładzie dwu jurysdykcji na rysunku 2 mogą być interpretowane jako obraz dychotomii pomiędzy gospodarkami rozwiniętymi a gospodarkami „zapóźnionymi” w odniesieniu do determinant EKC. Gospodarki rozwinięte są zwykle albo liderami w opracowywaniu nowych, przyjaznych dla środowiska naturalnego (choć najczęściej kapitałochłonnych) technologii, albo liderami w adaptowaniu takich technologii, jeżeli zostały one opracowane gdzie indziej. W przeciwieństwie do nich w gospodarkach słabiej rozwiniętych dominują technologie pracochłonne i - na wystarczająco wysokim poziomie rozwoju gospodarczego 
- zazwyczaj w większym stopniu negatywnie wpływające na środowisko. Wraz ze wzrostem presji na konsumpcję (związanym ze wzrostem produkcji), może to prowadzić $\mathrm{w}$ tych jurysdykcjach do poważnych napięć związanych $\mathrm{z}$ ochroną środowiska. Należy jednak podkreślić, że niezależnie od tego pewne przykłady rozwoju (np. Korei Południowej ${ }^{5}$ ) wskazują, że stosunkowo powoli przejmując i adaptując nowe technologie, jurysdykcje „zapóźnione” są w stanie nawet uzyskać premię za nieponoszenie początkowych ciężarów wytworzenia i rozwoju najnowocześniejszych technologii. Na tę prawidłowość wskazują także predykcyjne teorie handlu zagranicznego, w szczególności teoria międzynarodowego cyklu życia produktów Wellsa-Vernona ${ }^{6}$. Ta bowiem wskazuje, że technologie ochrony środowiska wykorzystywane w państwach wiodących gospodarczo są prędzej czy później przejmowane przez państwa o słabszej pozycji w tym zakresie. W tym kontekście EKC może być traktowana jako jedna z istotnych wskazówek (czy wręcz determinant) co do modelu działania międzynarodowego cyklu życia produktów.

\section{Wymiar jurysdykcyjny środowiskowej krzywej Kuznetsa i zagadnienie wspólnej odpowiedzialności za jego stan}

Jednym z zasadniczych problemów zastosowania EKC w analizie naukowej dotyczących relacji międzypaństwowych jest to, że jurysdykcjami, do których taka analiza się odnosi, są właśnie państwa. Z punktu widzenia polityki publicznej jedną z atrakcyjniejszych, predykcyjnych właściwości EKC jest to, że można na niej wyznaczać pozycję poszczególnych państw. Na podstawie tego plasowania można odpowiednio kształtować politykę publiczną każdego państwa w dziedzinie ochrony środowiska, zwłaszcza zaś odpowiednio kształtować jego relacje międzynarodowe w tym zakresie. Jednocześnie należy zauważyć, że państwa są różnie uposażone w sensie ekonomicznym - mają różne rozmiary w ujęciu terytorialnym, zamieszkują je różne co do wielkości populacje, ich środowisko naturalne jest także bardzo zróżnicowanie. Różne jest kształtowanie granic poszczególnych państw i różna charakterystyka fizyczna ich terytorium. Różne jest ponadto dziedzictwo strategiczne tych państw, tzn. uwarunkowania ich rozwoju, wynikające z przyjętych wcześniej decyzji dotyczących polityki gospodarczej (path dependence). Zasadniczo różne co do swoich przyczyn, uwarunkowań, przebiegu i implikacji są zatem problemy środowiskowe występujące

5 Zob. np. Y.W. Rhee, B. Ross-Larson, G. Pursell, Korea's Competitive Edge: Hanging the Entry into World Markets, The Johns Hopkins University, Baltimore 1984.

6 Zob. R. Vernon, International Investment and International Trade in the Product Cycle, "Quarterly Journal of Economics" 1966, Vol. 80, s. 190-207. 
np. w Luksemburgu i w Niemczech, inne w Chile i Brazylii, inne w Czadzie i Kenii. Należy ponadto zauważyć, że z punktu widzenia antropogenicznych obciążeń środowiskowych granice państw są wyznaczone arbitralnie - tzn. nie mogą być racjonalnie uzasadnione. Ze względu na występujące pomiędzy państwami różnice, najczęściej nie są one jurysdykcjami optymalnymi z punktu widzenia polityki publicznej. W wypadku państw bardzo małych, rozmiar ich jurysdykcji jest tak niewielki, że w odniesieniu do większości przypadków gospodarczego wykorzystywania środowiska naturalnego nie są one w stanie formułować i prowadzić własnej sensownej, proaktywnej polityki ochrony środowiska, lecz muszą się zdać na własną aktywność międzynarodową, dzięki której mogą one wpływać na zobowiązania państw większych, a przez to kształtować stan środowiska u siebie ${ }^{7}$.

W tym kontekście, z teoretycznego i praktycznego punktu widzenia, kwestia wartości predykcyjnej EKC wymaga pewnego uściślenia. W EKC zwykle przyjmuje się, że trajektoria zmiany zaobserwowana w jednej jurysdykcji powtórzy się w drugiej. Nie jest to założenie w pełni uzasadnione przede wszystkim $z$ uwagi na:

a) wspomniany już arbitralny charakter samych jurysdykcji, które brane są tu pod uwagę - w EKC uwzględnia się państwa albo regiony, wyodrębnione przecież nie na podstawie analizy optymalnego poziomu świadczenia i optymalnej wielkości grupy świadczeniobiorców, lecz na podstawie decyzji politycznych, najczęściej odzwierciedlających jakieś racje historyczne albo etniczne,

b) zróżnicowaną konfigurację przestrzenną poszczególnych jurysdykcji, dla których rozkłady ciężarów kosztów zewnętrznych mogą być bardzo różne, choćby dlatego, że np. proces zanieczyszczenia powietrza przebiega inaczej w górach, a inaczej na nizinach, inaczej w pasie nadmorskim, a inaczej w dolinach górskich,

c) istnienie w zakresie technologicznego komponentu EKC (uwzględnianego w ramach efektu redukcji) zjawisk zmniejszającego się kosztu przejęcia nowych technologii oraz występowania zjawiska krzywej uczenia się (learning curve), co może znacząco obniżyć koszty zmiany technologicznej oraz ją przyśpieszyć.

Ostatni ze wspomnianych argumentów opiera się na tej logice, że jurysdykcje podążające śladami jurysdykcji najzamożniejszych (będących w awangardzie ograniczania szkodliwych form gospodarczego korzystania ze środowiska) są zwykle w stanie osiągnąć punkty przełamania EKC wcześniej (na niższym poziomie zamożności) niż wspomniani liderzy. Będzie tak wtedy, gdy zdołają one skorzystać ze swoistej premii późnego przyjęcia technologii - m.in. zgodnie ze wspomnianą

7 A. Nowak-Far, Krzywa Kuznetsa a wielość jurysdykcji fiskalnych, „Studia z Polityki Publicznej” 2014, $\mathrm{nr}$ 1, s. 58-79; A. Nowak-Far, Międzynarodowe (międzyjurysdykcyjne) fiskalne implikacje środowiskowej krzywej Kuznetsa, w: Jedność i wartość. Zbiór studiów dedykowanych Profesor Marii Gintowt-Jankowicz, red. J. Pastwa, Z. Cieślak, K. Sawicka, W. Federczyk, KSAP, Warszawa 2014, s. 259-280. 
już ogólniejszą logiką międzynarodowego cyklu życia produktów, choć z pewnością także na zasadzie zwykłych korzyści imitacyjnych (jeżeli tylko możliwość imitacji istnieje) albo korzyści późnego użytkownika technologii ${ }^{8}$. Wszystkie te okoliczności mają istotne znaczenie, gdyż modyfikują kształt środowiskowej krzywej Kuznetsa, przyjęcia modelu oddziaływania (zachęty i zniechęcania) w zakresie polityki ochrony środowiska - a co za tym idzie determinacji rozkładu kosztów pomiędzy jurysdykcje wtedy, gdy są one składowymi większych jednostek terytorialnych bądź pozostają w układzie je integrującym.

W jurysdykcjach zintegrowanych, składających się z mniejszych części składowych (takich jak np. USA czy rynek wewnętrzny UE), taka sytuacja wpływa na możliwość obniżenia zagregowanego dla tej dużej całości całkowitego kosztu społecznego ochrony środowiska naturalnego w długim okresie. Sprzyja to przyśpieszeniu osiągnięcia przez „zapóźnione” jurysdykcje składowe punktu przełamania EKC. Warunkiem tego przyśpieszenia jest jednak rozciągnięcie procesu zmiany technologicznej w czasie, tzn. pozostawienie całości jurysdykcji pod rządami reguł wymagających zastosowania dotychczasowej technologii ochronnej albo zastosowania technologii nowej, która jednak nie rodzi dla „zapóźnionych” składowych jurysdykcji dodatkowych kosztów. Jeżeli jednak następuje zjawisko przejścia w tym zakresie na droższe nowe technologie i jeżeli dla całej integrowanej jurysdykcji stają się one wymaganym standardem (a więc, innymi słowy, ich stosowanie jest wymuszone regulacyjnie), spowoduje to powstanie oczywistych asymetrii warunków rozwoju gospodarczego.

Regulacyjne wymuszenie określonego standardu ochrony środowiska ( $\mathrm{z}$ jego, wspomnianą już, implikacją technologiczną) może być oczywiście interpretowane jako wprowadzenie - na poziomie międzyjurysdykcyjnym - reguł internalizacji kosztów zewnętrznych. Warto jednak zwrócić uwagę, że nie mamy do czynienia z prawidłowością statyczną - efektywna internalizacja wymaga bowiem przymuszenia producentów do pokrycia pełnego krańcowego kosztu korzystania przez nich ze środowiska naturalnego (zwłaszcza zaś kosztu zanieczyszczenia, które generują lub wyczerpania zasobów środowiska). W takim wypadku zależność zinternalizowanych korzyści (dochodów) i kosztów zewnętrznych (tj. wszelkich form presji środowiskowej) określą zarówno właściwości używanej przez producentów technologii, jak i elastyczność ich popytu na korzystanie ze środowiska naturalnego w procesie produkcji'. Te dwie determinanty mogą zwiększać skłonność także podmiotów gospodarczych działających w jurysdykcjach „zapóźnionych” do przenoszenia ich działalności poza jurysdykcję

8 Zob. np. A.D. Chandler, Scale and Scope: The Dynamics of Industrial Capitalism, Belknap Press, Cambridge 1990, s. 593-628.

9 R. Lopez, The Environment as a Factor of Production: The Effects of Economic Growth and Trade Liberalization, "Journal of Environmental Economics and Management" 1994, Vol. 27, s. 163-184. 
zintegrowaną, w której obowiązują wysokie standardy ochrony środowiska. Przeczyłoby to powszechnemu przekonaniu, wyrażanemu w literaturze, że proces ten dotyczy - i to w dominującym stopniu - jurysdykcji gospodarczo zaawansowanych ${ }^{10}$. Jednocześnie takie przenoszenie działalności powoduje wystąpienie drugiego, negatywnego, skutku w postaci niemożności wytworzenia w państwach zaawansowanych - przynajmniej w długim okresie - branżowo skoncentrowanych przewag konkurencyjnych „ciągniętych” przez wymagającą regulacji ochronę środowiska ${ }^{11}$.

Środowiskowa krzywa Kuznetsa, na której uplasowano co najmniej dwa państwa, może być interpretowana jako obraz asymetrii możliwości produkcyjnych tych podmiotów. Taki sposób interpretacji zwraca uwagę nie tylko na różnice sytuacji już zastanej, ale również na zróżnicowane możliwości korzystania z narzędzi ochrony środowiska, które zgodnie z regułą optymalizacyjną (dotyczącą także pożądanego kształtu regulacji prawnej), powinny być tak dobrane, by odzwierciedlać „najlepszą dostępną technologię niewiążącą się z nadmiernymi kosztami” (best available technology not entailing excessive costs - co określa się także jako formułę BAT). BAT jest jednak formułą asymetryczną $\mathrm{w}$ tym sensie, że - ze wspomnianych już powodów zróżnicowania jurysdykcji - w każdej z nich „nadmierne koszty” będą znaczyły co innego.

\section{Zasady wzajemności istotne w kontekście środowiskowej krzywej Kuznetsa}

W kontekście EKC, przynajmniej w odniesieniu do państw małych, granice jurysdykcji regulacyjnych (granice państw), przez swą arbitralność, uniemożliwiają właściwe formułowanie i wykonywanie odpowiedniej polityki publicznej dotyczącej ochrony środowiska naturalnego w każdym możliwym jej aspekcie. $Z$ tego powodu jurysdykcje regulacyjne muszą ze sobą współpracować w wymiarze międzyjurysdykcyjnym (w tym międzynarodowym). Działając w tym kontekście, w wymiarze fundamentalnym są one wobec siebie zrelacjonowane tak, że ustalanie przez nie zasad współpracy, a więc i przyjętych reguł prawnych dotyczących ochrony środowiska $\mathrm{w}$ warunkach różnego ich uplasowania na EKC można zinterpretować w kategoriach gier - jako grę, w której w warunkach zróżnicowania własnych preferencji jej uczestnicy poszukują równowagi Nasha. Tę osiągają wtedy, gdy ich własne działanie jest dopasowane do spodziewanych działan innych podmiotów uczestniczących

10 Zob. np. taki konwencjonalny pogląd w: G. Grossman, A. Krueger, op.cit., s. 371-372.

11 Zob. argumentację wiążącą wysoki poziom wymaganych standardów działania w tym zakresie $\mathrm{z}$ wytworzeniem w długim okresie przewag konkurencyjnych np. w: M.E. Porter, C. van der Linde, Green and Competitive, "Harvard Business Review" 1995, s. 120-134. 
w grze. Innymi słowy, równowaga Nasha powstaje wtedy, kiedy odpowiedź na strategię innych (maksymalizujących ich użyteczność) jest taka własna strategia każdego uczestnika gry, która maksymalizuje jego własną użyteczność12 ${ }^{12}$ W takim wypadku najbardziej efektywne (gdy idzie o ostateczny rezultat mierzony użytecznością wszystkich uczestników gry) są gry oparte nie na swoistej „realizacji” konfliktu (w której ktoś wygrywa, a ktoś przegrywa, przez co wynik gry jest zerojedynkowy, 1:0), lecz które opierają się na jakiejś formule koordynacji działań, gdyż ta gwarantuje większe korzyści. Modelem przedstawiającym przykładowo tego rodzaju sytuację (zapożyczonym z pracy K. Binmore’a ${ }^{13}$ ) jest taki, w którym dla dwu uczestników gry istnieje wyjściowo 10 różnych możliwości realizacji sprzecznych interesów. Każdej możliwości przypisana jest określona (przyjęta arbitralnie) wartość - tym wyższa, im wyższa jest jej użyteczność dla gracza, np.:

Tabela 1. Hipotetyczne wartości alternatywnych rozwiązań negocjacyjnych dla dwu państw - graczy w kontekście EKC

\begin{tabular}{|l|r|r|r|r|r|r|r|r|r|r|}
\hline \multicolumn{1}{|c|}{ Rozwiązanie } & 1 & 2 & 3 & 4 & 5 & 6 & 7 & 8 & 9 & 10 \\
\hline Użyteczność X & 0 & 6 & 16 & 19 & 22 & 28 & 34 & 40 & 44 & 46 \\
\hline Użyteczność Y & 36 & 36 & 34 & 32 & 30 & 26 & 22 & 18 & 8 & 0 \\
\hline
\end{tabular}

Źródło: K. Binmore, Natural Justice, Oxford University Press, Oxford 2005, s. 22.

W przedstawionym układzie wykluczone w ogóle są rozwiązania 1 i 10, gdyż $\mathrm{w}$ ogóle nie są do przyjęcia przez jednego z graczy (rozwiązanie 1 nie jest zupełnie akceptowane przez gracza X, zaś 10 przez gracza Y). Każda inne możliwość daje graczom jakieś korzyści, choć rozkładają się one nierównomiernie - przy czym nierównomierność ta jest różna dla różnych możliwych wyborów. Może być ona przedstawiona graficznie w postaci następującego rysunku:

Założeniem wszystkich wyborów ujętych na rysunku 3 (odbiegającym istotnie od założeń czystych gier niekooperacyjnych Nasha) jest uczestnictwo w grze tylko dwóch podmiotów (lub dwu grup podmiotów o idealnie homogenicznych interesach), z których każdy ma doskonałą informację o preferencjach drugiej strony (a więc o tym, jak wartościowy jest dla niej każdy z rozważanych możliwych kompromisów). Przez to każdy uczestnik jest w stanie określić koszty alternatywne każdej z nich. W układzie tym zakłada się także równą wyjściową pozycję przetargową każdego podmiotu lub homogenicznej co do preferencji grupy podmiotów. Każda z określonych w tabeli 1 możliwości (z przypisanym jej rozkładem korzyści i kosztów dla każdego

12 J.F. Nash, Non-cooperative Games, "Annals of Mathematics" 1951, Vol. 54, No. 2, s. 286-295.

13 K. Binmore, Natural Justice, Oxford University Press, Oxford 2005, s. 22. 
gracza) jest wyrysowana graficznie. Którykolwiek punkt przedstawiony w zbiorze punktów X (poniżej krzywej idącej od punktu 1 do 10) przedstawia rozkład korzyści i kosztów wynikających z ich możliwych decyzji. Punkt D wyznacza taką sytuację, która - jako jedyna - jest zupełnie nieefektywna (nie prowadzi bowiem do zawarcia jakiegokolwiek kompromisu). Pozostałe zapewniają równowagę Nasha, jednak przy różnych poziomach efektywności dla każdego uczestnika gry i przy różnych poziomach efektywności całkowitej - dla wszystkich z nich.

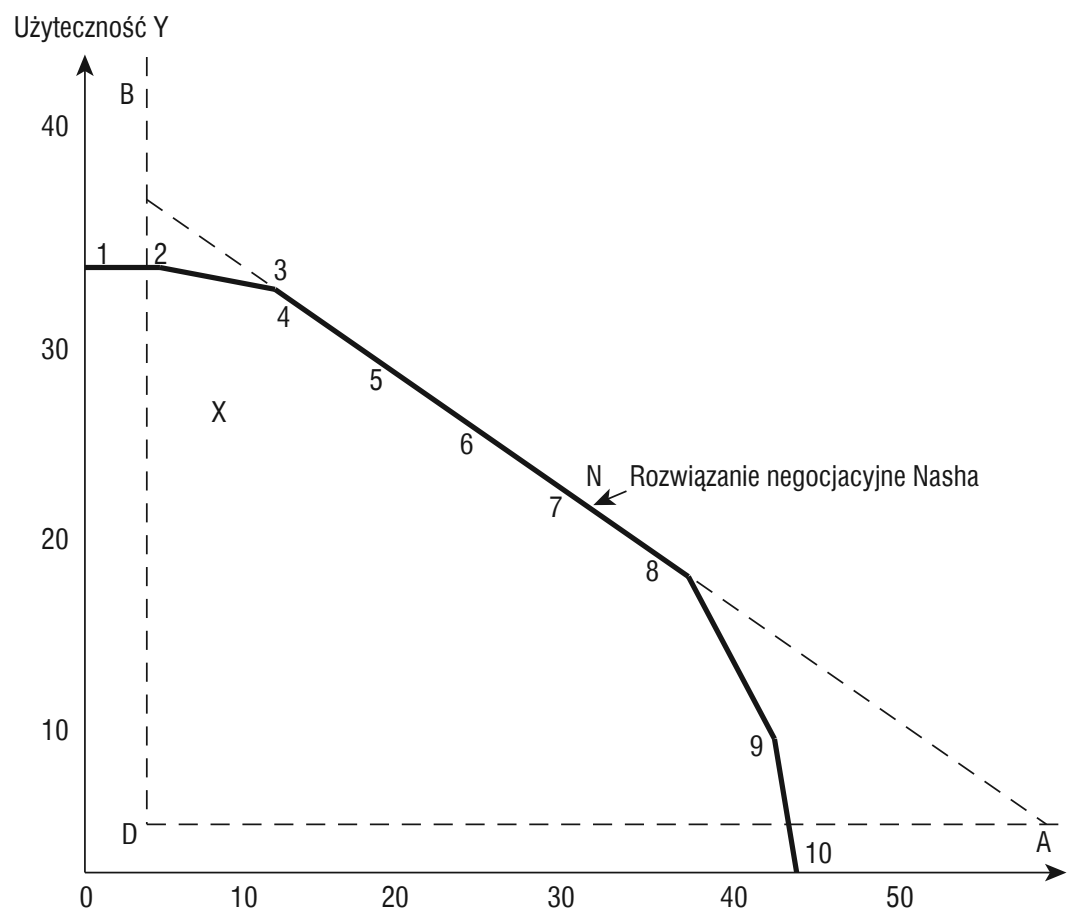

Rysunek 3. Uproszczone przedstawienie korzyści i kosztów przetargu negocjacyjnego. Gra dwupodmiotowa przy założeniu pełnej informacji uczestników o ich własnych preferencjach

Źródło: K. Binmore, Natural Justice, Oxford University Press, Oxford 2005, s. 24.

Tak zwane rozwiązanie przetargowe Johna Nasha ${ }^{14}$, które tu powstaje, istnieje dlatego, że zagregowana wartość korzyści wszystkich uczestników gry wtedy, gdy zawierają oni kompromis, jest większa od zagregowanej korzyści, którą mają oni przy braku takiego kompromisu. Proporcje korzyści z tych dwóch alternatywnych rozwiązań są optymalne w punkcie 7 na rysunku 1 (oznaczonym jako punkt N).

14 J.F. Nash, The Bargaining Problem, "Econometrica” 1950, No. 15, s. 155-162. 
W tym bowiem punkcie rezultaty mierzone polami prostokątów dla obu podmiotów zawierających kompromis wynoszą $(34-4) \times(22-2)=600$, a więc wartość najwyższą przy porównaniu $\mathrm{z}$ innymi możliwymi kompromisami (od 2 do 6 oraz od 8 do 9 , przy całkowitym pominięciu nieefektywnych rozwiązań 1 oraz 10). Rozwiązanie przetargowe Nasha w tej postaci niekoniecznie musi odpowiadać warunkom realnych negocjacji, w których strategia przetargowa jednej ze stron może np. polegać na sformułowaniu żądania odpowiadającego jakiemukolwiek innemu punktowi od 2 do 9 na krzywej 1-10 przy sformułowaniu gotowości odstąpienia przez nią w ogóle od negocjacji. Negocjacje mogą być także prowadzone w warunkach lepszej siły przetargowej jednej ze stron (np. w wyniku istniejącej asymetrii informacyjnej). Rozkład rezultatów (korzyści i kosztów) będzie także musiał być przedstawiony inaczej w razie tak zróżnicowanych sytuacji obu podmiotów uczestniczących w grze, że owe rezultaty będą musiały być ważone z uwzględnieniem szczególnych czynników o tym zróżnicowaniu ważących. Sytuację tę można przedstawić jak na rysunku 4:

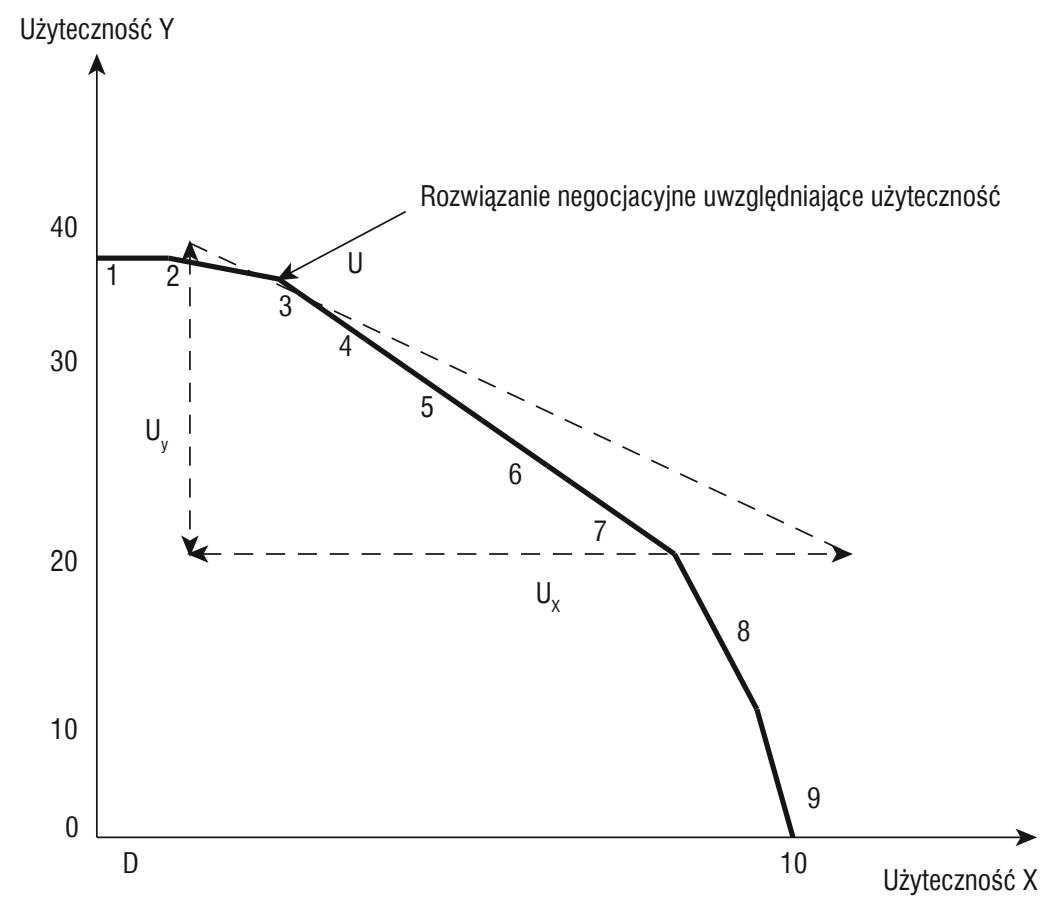

Rysunek 4. Uproszczone przedstawienie korzyści i kosztów przetargu negocjacyjnego (gra dwupodmiotowa i założenie pełnej informacji uczestników) z uwzględnieniem różnic użyteczności poszczególnych rozwiązań dla stron przetargu

Źródło: K. Binmore, Natural Justice, Oxford University Press, Oxford 2005, s. 31. 
Rysunek 4 przedstawia sytuację, w której każdy z możliwych kompromisów może być ważony jego założoną użytecznością dla każdego z dwóch uczestników gry. Dla rozwiązania 3 proporcja owych wag użyteczności dla gracza $\mathrm{Y}$ wobec gracza $\mathrm{X}$ ma się jak 1:2 (co oznacza, że użyteczność tego rozwiązania $\mathrm{U}_{\mathrm{y}}$ jest dla gracza $\mathrm{Y}$ dwa razy mniejsza niż dla gracza $X$, dla którego - $w$ wymiarze bezwzględnym wynosi ona $\mathrm{U}_{\mathrm{x}}$ ). Stąd w konkretnym położeniu rozwiązania 3 zagregowana wartość korzyści dla obu graczy wynosi: $16 / 2+34 / 1=42$ i jest największa.

W wypadku ochrony środowiska nie ma znaczącej asymetrii informacyjnej $\mathrm{z}$ uwagi na to, że o zasadniczych preferencjach informuje po prostu realizowana $\mathrm{w}$ danej jurysdykcji polityka w tym zakresie. Jeżeli już taka asymetria występuje, to może ona dotyczyć jedynie kwestii tego, z jaką intensywnością eksponowane będą znane preferencje oraz jaki będzie skład tworzonych koalicji negocjacyjnych. Zachowania kooperacyjne mają tu istotne znaczenie dla realizacji interesów wszystkich uczestników gry. Skłonność do kompromisu jest tu spora, choć ograniczona asymetrycznym rozkładem kosztów niektórych rozwiązań, wynikającym właśnie z prawidłowości ujętych w EKC. Z uwagi na strukturę konsumpcji dóbr wytwarzanych w ramach polityki publicznej ochrony środowiska polityka ta oparta jest silnie za zasadzie wzajemności.

Wzajemność jest kategorią relacyjną. Wymaga istnienia co najmniej dwu podmiotów, które mogą sobie cokolwiek świadczyć. Świadczenia determinujące charakter relacji wzajemnych w kontekście ochrony środowiska mogą przybierać formy identyfikowane w nauce prawa jako facere (czynienie ${ }^{15}$ ), omittere (zaniechanie) i pati (znoszenie). W odniesieniu do możliwych do zastosowania reguł prawnych w tym zakresie te formuły się ze sobą splatają kontyngentnie, tj. w zależności od konkretnej sytuacji, w której znajdują się osoby uczestniczące w danym stosunku.

Bez względu na konkretną sytuacyjną postać prosty model wymiany świadczeń - albo (w ujęciu negatywnym) dolegliwości w symultanicznym układzie czasowym - nazywa się modelem wzajemności bezpośredniej (direct reciprocity) ${ }^{16}$. Warto zwrócić uwagę, że w ujęciu idealizującym, zakładającym równowartość świadczeń, prowadzi on do szczątkowej równości binarnej, w której zawsze dwie osoby w jakiejś konkretnej relacji wyrównują swoje rachunki albo (w postaci mniej radykalnej) o takie wyrównanie się starają. W dziedzinie międzynarodowych aspektów ochrony środowiska, zwłaszcza zaś w kontekście asymetrii ujawnionej w EKC, ważniejsze są jednak złożone postacie wzajemności, określane także jako „wzajemności rozszerzone” (extended

$15 \mathrm{~W}$ tych ramach również dare (dawania).

16 S.-Ch. Kolm, Reciprocity: An Economics of Social Relations, Cambridge University Press, Cambridge 2008, s. 35-36. 
reciprocities $)^{17}$. Do kategorii złożonych relacji wzajemnych można zaliczyć również te, w których dostrzegamy brak symultanicznej lub bliskiej symultaniczności korelacji czasowej pomiędzy jednym działaniem a odpowiedzią na nie. Złożonym typem relacji jest także ta, w której działanie wzajemne z jakiegoś powodu ma wręcz nie powodować żadnej wzajemności skoncentrowanej, lecz raczej nastąpić w formule rozproszonej ${ }^{18}$. Jeszcze innym, bardzo szczególnym typem świadczenia wzajemnego są wszystkie te, które obecne pokolenie czyni na korzyść pokoleń przyszłych, z którymi nie może mieć bezpośredniej styczności ${ }^{19}$. Ta ostatnia postać wzajemności jest najbardziej zgeneralizowana, istotna dla reguł prawa ochrony środowiska w ogóle.

Nadając wspomnianym obserwacjom bardziej zdyscyplinowaną formułę naukową, ale i znacząco poszerzając samą koncepcję wzajemności, S.-Ch. Kolm dzieli złożone postacie wzajemności na określone typy, nazywane przez niego strukturami wzajemności (bądź strukturami recyprokacyjnymi, reciprocal structures). Owe struktury są charakteryzowane przez istotę relacji pomiędzy z jednej strony - faktami (którymi są działania, odczucia, postawy i oceny obecne wśród ludzi we wzajemnych ich relacjach) bezpośrednio odnoszonymi do motywacji (którymi są poszukiwanie równowagi, sympatia, chęć kontynuowania relacji), a z drugiej strony - ludźmi (indywidualnymi osobami bądź ich grupami), których owe fakty mogą dotyczyć. Opierając się na różnicach właśnie w tym zakresie, Kolm wyróżnia następujące struktury recyprokacyjne:

a) podstawowe (basic), w których występują tylko dwa podmioty (w rozważanym przypadku są to państwa) i dwa fakty - zaś odwzajemnienie może mieć postać prostą albo złożoną; w tym drugim przypadku odwzajemnienie może nie być jednorazowe ani nie występować w bezpośredniej motywacyjnej relacji do działania je inicjującego,

b) rozszerzone (extended), w których liczba podmiotów w relacji przewyższa 2, i że występuje tu co najmniej podmiot I inicjujący działanie $(\mathrm{I} \rightarrow)^{20}$, podmiot, wobec którego I podjął bezpośrednio działanie $(\rightarrow A)$ oraz inny podmiot $(B \ldots$, n); struktury rozszerzone mogą mieć postać:

- uogólnioną (generalized), wtedy gdy jeżeli $\mathrm{I} \rightarrow \mathrm{A}$, to $\mathrm{A} \rightarrow \mathrm{B}$ lub nawet $\mathrm{A} \rightarrow(\mathrm{n}-\mathrm{I})$,

- ogólną (general), wtedy gdy, tak samo, $\mathrm{I} \rightarrow \mathrm{A}$, to $\mathrm{A} \rightarrow \mathrm{B}$ lub nawet $\mathrm{A} \rightarrow(\mathrm{n}-\mathrm{I})$, jednak z zastrzeżeniem, że świadczenie inicjujące jest dokonane wobec B lub każdego

17 Ibidem, s. 37-39.

18 Odwzajemniającą nie jest wtedy ta osoba, wobec której nastąpiło świadczenie inicjujące relację, lecz jakikolwiek inny członek społeczności bądź wręcz pewna część tej społeczności lub cała ta społeczność.

$19 \mathrm{~Np}$. w kontekście finansowania polityki publicznej poprzez dług publiczny czy w odniesieniu do ochrony środowiska.

20 Odwzajemnienie (wobec I) można zatem oznaczyć zatem „I $\leftarrow$ ”. Gdy wiemy, że odwzajemnia A, zapis będzie przedstawiał się tak: „I $\mathrm{I} \leftarrow$ ”. 
innego podmiotu (n-I) z uwagi na to, że należą one do jakiejś konkretnej grupy społecznej albo gdy świadczenie jest definiowane przez I jako takie, które jest na rzecz całej liczebnej społeczności, którego B lub (n-I) są jedynie członkami,

- zwrotną (reverse), wtedy gdy jeżeli $\mathrm{I} \rightarrow \mathrm{A}$, to $\mathrm{I} \leftarrow \mathrm{B}$ lub $\mathrm{I} \leftarrow(\mathrm{n}-\mathrm{A})$, co w każdym razie oznacza odwzajemnienie działania I przez podmiot trzeci, niebędący bezpośrednim beneficjentem pierwotnego działania I,

- łańcuszkową (chain), zachodzącą wtedy, gdy świadczenie I wywołuje jakąkolwiek taką reakcję, że $\mathrm{I} \rightarrow \mathrm{A} \rightarrow \mathrm{B} \rightarrow(\ldots \mathrm{n})$, przy czym „n” nie musi być nieskończonością ani nawet dużą liczbą; wystarczy zatem, by łańcuszek świadczeń kończył się na podmiocie B albo może obejmował jakąkolwiek liczbę podmiotów większą niż 2 .

Typologia Kolma eksponuje naturę systemu świadczeń, których względnie egoistycznie postępujący uczestnicy gry (którymi - w moim przekonaniu - mogą być także państwa) oczekują. Są oni bowiem skłonni akceptować nie tylko świadczenia oparte na modelu prostej wzajemności (co oznacza, że są gotowi także na indywidualne świadczenia wzajemne), lecz także świadczeń w modelach bardziej złożonych, w których docenia się np. nie tyle świadczenie, ile np. to, że można go w sposób uzasadniony oczekiwać w bliżej nieokreślonej przyszłości, w odpowiedniej konfiguracji sytuacyjnej (a więc w sytuacji niezindywidualizowanego świadczenia typu „A $\leftarrow$ (n-A)”, gdzie „n” oznacza jakąkolwiek grupę podmiotów (oczywiście poza samym A, co uwzględniono w zapisie).

Złożone postaci wzajemności rozszerzonej mają szczególne znaczenie dla interpretowania zachowań państw w kontekście kształtowania przez nie preferencji dotyczących polityki ochrony środowiska oraz realizowania tych preferencji na forach międzynarodowych. Z uwagi na wzajemną przejrzystość zasadniczych kierunków ich polityki ochrony środowiska, możliwość prowadzenia takiej polityki, która jest jawnym przypadkiem ,jazdy na gapę" jest bardzo ograniczona - zasadniczo do przypadków, w których chodzi o „niemobilne” presje środowiskowe (np. w postaci wycinki niewielkich części puszcz, które powinny być chronione, czy zabijania dzikich zwierząt w ich naturalnym habitacie). W wypadku presji mobilnych ,jazda na gapę" jest szczególnym przypadkiem polityki beggar-thy-neighbour, a ta stwarza presję negocjacyjną państw dotkniętych jej skutkami na odpowiednią jej korektę. Implikuje to, że wytwarza się między takimi państwami sieć oczekiwań obliczonych na różnorodne świadczenia wzajemne, które są najsilniejsze pomiędzy podmiotami umiejscowionymi na przeciwległych ramionach EKC.

W odniesieniu do polityki ochrony środowiska istnieje ponadto zasadnicza zgodność państw co do jej długofalowych celów. Zasadnicza sprzeczność interesów, ujawniona w EKC, przejawia się w wyborach celów krótko- i średniookresowych. Te bowiem są znacząco determinowane przez właściwe każdemu państwu krzywe 
możliwości produkcyjnych oraz przez możliwości finansowania poważniejszych inwestycji w technologie BAT. Z uwagi na zasadniczą charakterystykę EKC część państw o zdecydowanie gorszej charakterystyce w tym zakresie dysponuje bardziej wartościowym środowiskiem naturalnym, bywa że w znaczeniu globalnym. Oczekiwanie, że staną się one czymś w rodzaju rezerwatu dla mieszkańców tej części świata, która plasuje się w korzystniejszej pozycji na EKC, jest po prostu nieuzasadnione, chyba że utrzymanie dobrego stanu środowiska naturalnego potraktuje się jako inwestycję, za którą odpowiedzialność musi wziąć cała społeczność międzynarodowa. W takim razie ochronę środowiska w jednym państwie należałoby potraktować jako świadczenie na rzecz wszystkich innych państw i stosownie do tego - na zasadzie wzajemności - zapewnić współfinansowanie wspomnianej inwestycji. Implikuje to konieczność współfinansowania owych inwestycji albo w postaci pożyczek, albo subsydiów (także w formie rzeczowej, np. poprzez przekazanie odpowiedniej technologii - przez co naruszona zostałaby „wolnorynkowa” logika międzynarodowego cyklu życia produktów). Bez takiego systemu oczekiwanie dokonania przez takie państwa nakładów na ochronę środowiska albo powstrzymania się od inwestycji zwiększających obciążenie środowiskowe jest właśnie swoistym oczekiwaniem na możliwość ,jazdy na gapę” - tym razem tych państw, które przeszły już tę ścieżkę rozwoju, którą dopiero muszą przejść państwa słabiej rozwinięte.

Środowiskowa krzywa Kuznetsa może być interpretowana jako opis asymetrii uwarunkowań rozwoju gospodarczego i wynikających stąd sprzeczności interesów pomiędzy państwami. Owe asymetrie i sprzeczności znajdują swoje odzwierciedlenie w realizowanej przez nie wewnętrznie i poszukiwanej w przestrzeni międzynarodowej policy mix w dziedzinie ochrony środowiska. Na skomplikowanej mapie interesów i zależności naturalnie pojawiających się w kontekście ochrony środowiska muszą być uwzględnione korzyści i koszty zewnętrzne, które krajowa polityka ochrony środowiska poszczególnych państw stwarza. Z EKC wynika, że owe korzyści i koszty nie mogą być rozłożone równomiernie, co powoduje, że istotne jest zapewnienie takich rozwiązań międzyjurysdykcyjnych, które zapewniają identyfikację świadczeń opartych na wzajemności zgeneralizowanej i realizację ich w jakiejś formule wymagającej międzynarodowego porozumienia o wymianie świadczeń. Wzajemność, o której w tym wypadku mowa, ma charakter zgeneralizowany. Jej funkcją jest zapewnienie takich równowag Nasha, które długookresowo zapewniają najwyższy poziom efektywności. Taka konceptualizacja owej funkcji jest o tyle interesująca, że przecież równowagi Nasha nie wymagają kooperatywności, a jedynie prawidłowego rozpoznania zasadniczych 
interesów i realizujących je strategii. To zaś jest zadaniem łatwym w wypadku polityki ochrony środowiska, gdyż sam jej kształt i efekty dają się po prostu obserwować jako zespół zjawisk zachodzących w rzeczywistości. Niekooperatywność gry w tym zakresie nie jest ponadto pełna - $\mathrm{w}$ tym wypadku istnieje przecież zasadnicza zgodność większości państw co do ich fundamentalnych, długookresowych celów polityki środowiska. Ze względu na różnice, które można sprowadzić do różnego poziomu i przebiegu krzywej możliwości produkcyjnych (i krzywych ograniczenia budżetowego), sprzeczność interesów pojawia się w odniesieniu do tego, jak te cele strategiczne osiągnąć w krótkim i średnim okresie w warunkach, gdy w państwach różnie plasujących się na EKC istnieje różnie motywowana i różnie realizowana pokusa „jazdy na gapę”. Nie sposób również pominąć czystej wody deklaratywności intencji po stronie takich państw, których średnio- i krótkookresowa polityka gospodarcza jest prowadzona w sposób fundamentalnie sprzeczny z zasadami zrównoważonego rozwoju, a więc zwłaszcza taki, który powoduje nieodwracalne zmiany w środowisku naturalnym, np. w postaci zwykłego wyczerpania jego zasobów czy trwałej konfiguracji krajobrazu.

Możliwość skutecznej realizacji tej pokusy musi być eliminowana, gdyż w każdym przypadku jest przejawem polityki gospodarczej typu beggar-thy-neighbour. Możliwość pojawienia się tego modelu polityki stwarza presję negocjacyjną państw, które mogą być dotknięte jej skutkami, na odpowiednią jej korektę. Implikuje to, że wytwarza się między takimi państwami sieć oczekiwań obliczonych na różnorodne świadczenia wzajemne, które są najsilniejsze pomiędzy podmiotami umiejscowionymi na przeciwległych ramionach EKC. Państwa bardziej zaawansowane, uplasowane na wysokich poziomach dobrobytu i efektywności gospodarczej, będą zatem oczekiwały ograniczenia presji środowiskowej od państw, które dopiero dążą do osiągnięcia punktu przełamania EKC. Te zaś mogą rozsądnie oczekiwać, że wymaganie ograniczenia presji środowiskowej jest swoistą postacią nacisku na stworzenie przez nie korzyści zewnętrznych, które będą mogły być spożytkowane przez państwa zaawansowane. To zaś stwarza przestrzeń potencjalnej wymiany świadczeń wzajemnych: z jednej strony - przyjęcia przez państwa mniej zaawansowane rozwiązań ograniczających koszty przełamania EKC (tj. spłaszczających jej wierzchołek), a z drugiej strony - finansowania tego swoistego świadczenia przez państwa bardziej zaawansowane. Inną możliwością jest spetryfikowanie ukształtowanej relacji państw, której wyrazem jest EKC - ale to wymagałoby stałych i pokaźnych świadczeń dokonywanych przez państwa zaawansowane na rzecz tych położonych na przeciwległym krańcu tej krzywej. 


\section{Bibliografia}

Bartlett A.A., Reflections on Sustainability, Population Growth and the Environment, "Population and Environment" 1994, Vol. 16.

Binmore K., Natural Justice, Oxford University Press, Oxford 2005.

Chandler A.D., Scale and Scope: The Dynamics of Industrial Capitalism, Belknap Press, Cambridge 1990.

Grossman G.M., Krueger A.B., Economic Growth and the Environment, "Quarterly Journal of Economics" 1995, Vol. 110.

Islam N., Vincent J., Panayotou T., Unveiling the Income-Environment Relationship: An Exploration into the Determinants of Environmental Quality, Development Discussion Paper 1999, No. 701.

J.F., The Bargaining Problem, "Econometrica” 1950, No. 15.

Kolm S.-Ch., Reciprocity: An Economics of Social Relations, Cambridge University Press, Cambridge 2008.

Kuznets S., Economic Growth and Income Inequality, “The American Economic Review” 1955, Vol. 45.

Lopez R., The Environment as a Factor of Production: The Effects of Economic Growth and Trade Liberalization, "Journal of Environmental Economics and Management" 1994, Vol. 27.

Nash J.F., Non-cooperative games, “Annals of Mathematics” 1951, Vol. 54, No. 2.

Nowak-Far A., Krzywa Kuznetsa a wielość jurysdykcji fiskalnych, „Studia z Polityki Publicznej” 2014, nr 1.

Nowak-Far A., Międzynarodowe (międzyjurysdykcyjne) fiskalne implikacje środowiskowej krzywej Kuznetsa, w: Jedność i wartość. Zbiór studiów dedykowanych Profesor Marii Gintowt-Jankowicz, red. J. Pastwa, Z. Cieślak, K. Sawicka, W. Federczyk, KSAP, Warszawa 2014.

Panayotou T., Economic Growth and the Environment, Economic Survey of Europe 2003, Economic Commission for Europe.

Porter M.E., van der Linde C., Green and Competitive, "Harvard Business Review" 1995.

Rhee Y.W., Ross-Larson B., Pursell G., Korea's Competitive Edge: Hanging the Entry into World Markets, The Johns Hopkins University, Baltimore 1984.

Vernon R., International Investment and International Trade in the Product Cycle, "Quarterly Journal of Economics" 1966, Vol. 80.

Zamboni M., The Policy of Law: A Legal Theoretical Framework, Hart, Oxford 2007. 